\title{
HYPERTENSION IN EMPLOYEES OF A UNIVERSITY GENERAL HOSPITAL
}

\author{
Decio Mion Jr., Angela M. G. Pierin, Alberto P. Bambirra, Jorge H. Assunção, \\ Juliana M. Monteiro, Roberta Y. Chinen, Roger B. Coser, Vânia N. Aikawa, \\ Fernanda M. Cação, Mariana Hausen, Marcelo F. Vilibor, Nádia E. Aikawa, Sérgio \\ N. Konno and Roger B. Coser
}

MION Jr. D et al. Hypertension in employees of a University General Hospital. Rev. Hosp. Clín. Fac. Med. S. Paulo 59(6):329-336, 2004.

PURPOSE: To find out the prevalence of hypertension in employees of the Hospital and relate it to social demographic variables.

METHODS: Blood pressure measurement was performed with a mercury sphygmomanometer, using an appropriate cuff size for arm circumference, weight, and height in a population sample of 864 individuals out of the 9,905 employees of a University General Hospital stratified by gender, age, and job position.

RESULTS: Hypertension prevalence was $26 \%$ (62\% of these reported being aware of their hypertension and $38 \%$ were unaware but had systolic/diastolic blood pressures of $\geq 140$ and/or $\geq 90 \mathrm{~mm} \mathrm{Hg}$ at the moment of the measurement). Of those who were aware of having hypertension, $51 \%$ were found to be hypertensive at the moment of the measurement. The prevalence was found to be $17 \%, 23 \%$, and $29 \%(P<.05)$ in physicians, nursing staff, and "others", respectively. The univariate analysis showed a significant odds ratio for the male gender, age $\geq 50$ years, work unit being the Institute of Radiology and the Administration Building, educational level selementary school, length of work $\geq 10$ years, and body mass index $\geq 30 \mathrm{~kg} / \mathrm{m}^{2}$. The multivariate logistic regression model revealed a statistically significant association of hypertension with the following variables: gender, age, skin color, family income, and body mass index.

CONCLUSIONS: Hypertension prevalence was high, mainly in those who were not physicians or members of the nursing staff. High-risk groups (obese, non-white, men, low family income) should be better advised of prevention and early diagnosis of hypertension by means of special programs.

KEYWORDS: Hypertension. Arterial blood pressure measurement. Employee. Hospital.

Hypertension is an important cause of morbidity and mortality due to its high prevalence and severe consequences. ${ }^{1}$

Although there are no Brazilian surveys on hypertension prevalence among health care professionals, some regional studies reveal a prevalence ranging from $22 \%$ to $44 \%$ in the urban adult population, considering the hypertension criterion as blood pressure $\geq 140 / 90 \mathrm{~mm} \mathrm{Hg}{ }^{2-7}$

There are some studies in specific populations such as general employ- ees, ${ }^{8}$ civil construction workers, ${ }^{9}$ bank employees, ${ }^{10}$ university servants, ${ }^{11}$ and workers in a leather factory, ${ }^{12}$ revealing prevalences of $15 \%, 16 \%, 18 \%$, $22 \%$ and $56 \%$, respectively. In the health area, a study carried out in the city of Salvador, Bahia, with the members of a hospital nursing staff showed

From the Hypertension Unit, Hospital das Clínicas, Faculty of Medicine, University of São Paulo and the University of São Paulo Nursing School - São Paulo/SP, Brazil.

E-mail: deciomion@uol.com.br

Received for publication on December 11, 2003. Accepted for publication on April 15, 2004. a prevalence of $36 \% \cdot{ }^{13}$ Again, in the health area, physicians of a nonselected sample of 1,395 physicians from São Paulo State ${ }^{14}$ showed a prevalence of $26 \%$, and among the employees of a military hospital ${ }^{15}$ the prevalence was $8 \%$. Therefore, the prevalence is very different in the several groups studied because of the criteria applied for hypertension diagnosis and sample selection, among other factors.

Since the identification of prevalence in specific populations is funda- 
mental for planning hypertension preventive and therapeutic measures, it was decided that this topic would be investigated at Hospital das Clínicas, which is the largest hospital complex in Latin America, has a great number of employees working in different job positions, and therefore is able to provide a broad view on hypertension among health care employees.

Thus, this study aimed at identifying in employees of the referred hospital the following: a) hypertension prevalence; and b) associations and possible links between hypertension and demographic data, education, family income, body mass index, and aspects related to work, such as job position, work unit, work shift, and years of work.

\section{METHODS}

The study was approved by the Ethics Committee. Employees who agreed to participate in the study were included after signing an informed consent document.

The sample was stratified by gender, age, and job position (physicians, nursing staff, and "others"). A randomized selection of $10 \%$ of each variable was performed, and a sample of 864 individuals was calculated out of the 9,905 employees.

In terms of job positions, the employees were classified into 3 large groups: a) physicians; b) members of the nursing staff, including registered nurses, auxiliary nurses, nurse aids, and nurse technicians; and c) "others" other employees occupying administrative and management positions (tasks including skilled, semi-skilled, and nonskilled performance, nonoperational support tasks, and services).

Data were collected by interviews using a specific form that addressed the following aspects: a) identification gender, age, and skin color; b) education; c) social economical level family income; d) work job position, unit, shift, and years of work; and d) hypertension awareness of being hypertensive.

At the end of the interview, the following measurements were taken: a) arm circumference to identify the appropriate cuff size to be used; b) blood pressure; and c) weight and height to calculate the body mass index.

Both arm circumferences were measured without clothing in the middle third between the olecranon and the acromion with the arm stretched alongside the body.

Blood pressure measurement was taken according to the recommendations of the Fourth Brazilian Guidelines on Hypertension. ${ }^{16}$ An indirect method with an auscultatory technique using a suitably calibrated mercury sphygmomanometer (Baummometer, Desk Model, New York, EUA) was employed. The volunteers were in the sitting position and at rest for 10 minutes, had not eaten, had not ingested drinks containing alcohol or caffeine, and had not smoked for at least 30 minutes before the measurements. Additionally, the volunteers were asked to empty their bladders prior to the measurement. Blood pressure measurements were taken in the arm having the larger circumference. Three measurements or as many as necessary were taken with the "standard" (inflatable pouch 12 x 23 $\mathrm{cm})$ cuff until the difference between the last 2 readings was not higher than $4 \mathrm{~mm} \mathrm{Hg}$. In cases where the arm circumference was smaller than $24 \mathrm{~cm}$ or larger than $32 \mathrm{~cm}$, the same procedure was performed but using an "appropriate" cuff-to-arm circumference (inflatable pouch $9 \times 18 \mathrm{~cm}$ for arm circumferences smaller than $24 \mathrm{~cm}$, and $15 \mathrm{x}$ $33 \mathrm{~cm}$ for arm circumferences between 33 and $47 \mathrm{~cm}$ ). Blood pressure measurements were obtained using the arithmetic mean of the 2 last readings. Body weight was measured with the employees wearing light clothes and no shoes.
Body mass index was calculated with the formula weight $(\mathrm{kg}) /$ height $(\mathrm{m})^{2}$.

All observers were trained for measuring blood pressure and succeeded in the certification test to do so. The course consisted of theoretical exhibition followed by knowledge evaluation with an approval criterion of at least $80 \%$ of the 15 questions, as well as training with a specialist to solve doubts and to show the blood pressure measurement procedure. At the end of the course, an evaluation test was conducted with: a) a video that showed the mercury sphygmomanometer during blood pressure measurement and reproduced Korotkoff's sounds, consisting of 24 systolic and diastolic blood pressure measurements. Differences of a maximum of $\pm 2 \mathrm{~mm} \mathrm{Hg}$ and maximum 2 differences up to $\pm 4 \mathrm{~mm}$ $\mathrm{Hg}$ were accepted in the 24 measurements for approval (video "Standardizing Measurement", Shared Care, California, EUA); and b) an auscultatory test with a specialist using a double stethoscope and 3 measurements taken for 2 individuals. Differences of $\pm 4 \mathrm{~mm} \mathrm{Hg}$ and maximum 2 differences up to $\pm 6 \mathrm{~mm} \mathrm{Hg}$ were accepted in the 12 measurements. Moreover, all of the trainees underwent tonal and vocal audiometric tests at the Otorhinolaryngology Service which showed normal results.

The diagnosis of hypertension was established when: a) the employee was aware of having hypertension by answering positively the question, "Do you have high blood pressure disease?"; or b) systolic blood pressure level was $\geq 140 \mathrm{~mm} \mathrm{Hg}$ and/or diastolic blood pressure level was $\geq 90 \mathrm{~mm} \mathrm{Hg}$ at the moment of the measurement.

Data were presented as mean \pm standard deviation and absolute and relative frequencies. The statistical analysis was carried out by the Statistical Analysis System, using either the chi-square $\left(\chi^{2}\right)$ test, odds ratio test, or Fisher test for the classificatory vari- 
ables and variance analysis for the continuing variables. A multivariate analysis was performed with a logistic regression model on a selection of variables. Values of $P<.05$ were considered statistically significant.

\section{RESULTS}

Out of the sample of 864 individuals, a total of 810 people were interviewed due to the difficulty in locating some individuals in spite of 2 attempts to do so or because of their refusal to participate in the study. The sample (Tables 1, 2, and 3) consisted mainly of female employees (68\%), age group between 31 to 50 years $(64 \%)$, white skin color $(62 \%)$, high school education $(29 \%)$ and university graduated (34\%), family income ranging between US $\$ 400.00$ and US $\$ 1,600.00$ monthly $(59 \%)$ and $\mathrm{BMI}$ in the range of overweight or obesity levels (49\%). In terms of job positions, $11 \%$ were physicians,
$34 \%$ were members of the nursing staff, (registered nurses $=15 \%$, auxiliary nurses $=67 \%$, nurse aids $=16 \%$, and nurse technicians $=1 \%$ ), and the others $(55 \%)$ had different job positions. Regarding work units, most of the employees studied (41\%) were from the Central Institute. Concerning work shifts, most of the employees (84\%) worked in the daytime; with respect to years of work, the highest percentage (38\%) was represented by employees who had worked in the institution for 10 to 20 years.

Blood pressure was found to be higher $(P<.05)$ in men, age $>50$ years, non-white skin color, education $<$ elementary school level, family income $\leq \mathrm{US} \$ 400$, and BMI in the range of overweight and obesity levels. In terms of job positions, blood pressure was found to be higher $(P<.05)$ in employees whose job position fell in the "others" category, employees whose work unit was the Administration Building, and employees who had worked longer than 10 years. There was no dif- ference in blood pressure regarding work shifts (Tables 1, 2, and 3).

Hypertension prevalence was $26 \%$ in the employees, with most of these (62\%) being aware of having hypertension by answering positively ("yes") to the question: "Do you have high blood pressure disease?" and the others $(38 \%)$ who reported being unaware of their hypertension by having a systolic blood pressure level $\geq 140 \mathrm{~mm}$ $\mathrm{Hg}$ and/or diastolic blood pressure level $\geq 90 \mathrm{~mm} \mathrm{Hg}$ at the moment of the measurement. Of those who reported being aware of their hypertension, practically half $(51 \%)$ were found to be hypertensive at the moment of the measurement, and $49 \%$ were found to be normotensive. Among those who were unaware of their hypertension but who had high blood pressure levels at the moment of the measurement, a high percentage (91\%) answered negatively ("no") when asked if they had "high blood pressure disease", and 9\% answered they did not know if they had

Table 1 - Systolic blood pressure, diastolic blood pressure (mean $\pm \mathrm{SD}, \mathrm{mm} \mathrm{Hg}$ ) and hypertension prevalence in employees of a university general hospital according to the demographic data, education, and family income.

\begin{tabular}{|c|c|c|c|c|}
\hline Variable & Number $(\%)$ & $\begin{array}{l}\text { Systolic blood } \\
\text { pressure }\end{array}$ & $\begin{array}{l}\text { Diastolic blood } \\
\text { pressure }\end{array}$ & $\begin{array}{c}\text { Hypertension } \\
\text { prevalence }(\%) *\end{array}$ \\
\hline \multicolumn{5}{|l|}{ Gender * } \\
\hline 1. Male & $262(32)$ & $125 \pm 17$ & $83 \pm 12$ & 32 \\
\hline 2. Female & $548(68)$ & $117 \pm 17^{\alpha}$ & $77 \pm 12^{\alpha}$ & 22 \\
\hline \multicolumn{5}{|l|}{ Age $($ years $) *$} \\
\hline 1. $\leq 30$ & $138(17)$ & $112 \pm 11$ & $72 \pm 10$ & 8 \\
\hline 2. $31-40$ & $262(32)$ & $116 \pm 15$ & $77 \pm 11^{\alpha}$ & 17 \\
\hline 3. $41-50$ & $256(32)$ & $121 \pm 16^{\alpha \beta}$ & $81 \pm 12^{\alpha \beta}$ & 29 \\
\hline 4. $51-60$ & $132(16)$ & $131 \pm 20^{\alpha \beta \gamma}$ & $84 \pm 11^{\alpha \beta}$ & 51 \\
\hline 5. $>60$ & $22(3)$ & $128 \pm 18^{\alpha \beta}$ & $79 \pm 11$ & 55 \\
\hline \multicolumn{5}{|l|}{ Skin color $*$} \\
\hline 1. White & $506(62)$ & $118 \pm 16$ & $78 \pm 11$ & 22 \\
\hline 2. Mulatto & $152(19)$ & $122 \pm 19$ & $79 \pm 13$ & 27 \\
\hline 3. Black & $124(15)$ & $123 \pm 20^{\alpha}$ & $81 \pm 15$ & 35 \\
\hline 4. Oriental & $28(3)$ & $119 \pm 10$ & $80 \pm 8$ & 32 \\
\hline \multicolumn{5}{|l|}{ Education * } \\
\hline 1. Illiterate; able to read and write & $10(1)$ & $125 \pm 22$ & $84 \pm 14$ & 40 \\
\hline 2. Incomplete Elementary School & $67(8)$ & $131 \pm 22$ & $85 \pm 15$ & 48 \\
\hline 3. Elementary School graduate & $106(13)$ & $123 \pm 17^{\beta}$ & $80 \pm 13$ & 39 \\
\hline 4. Incomplete High School & $59(8)$ & $121 \pm 17^{\beta}$ & $80 \pm 11$ & 19 \\
\hline 5. High School graduate & $237(29)$ & $119 \pm 17^{\beta}$ & $78 \pm 12^{\beta}$ & 22 \\
\hline 6. Incomplete University degree & $55(7)$ & $118 \pm 15^{\beta}$ & $78 \pm 13^{\beta}$ & 16 \\
\hline 7. University degree graduate & $276(34)$ & $116 \pm 15^{\beta \gamma}$ & $78 \pm 10^{\beta}$ & 21 \\
\hline \multicolumn{5}{|l|}{ Family income* } \\
\hline 1. Up to US $\$ 400.00$ & $161(20)$ & $124 \pm 19$ & $81 \pm 13$ & 34 \\
\hline 2. From US $\$ 400.00$ to US $\$ 800.00$ & $256(32)$ & $119 \pm 16^{\alpha}$ & $78 \pm 13$ & 24 \\
\hline 3. From US $\$ 800.00$ to US $\$ 1,600.00$ & $218(27)$ & $120 \pm 18$ & $79 \pm 12$ & 25 \\
\hline 4. More than US $\$ 1,600.00$ & $168(21)$ & $116 \pm 13^{\alpha}$ & $78 \pm 10$ & 20 \\
\hline
\end{tabular}

$P<.05$ regarding gender, age, skin color, education, and family income; $\alpha: P<.05$ vs. $1 ; \beta: P<.05$ vs. $2 ; \gamma: P<.05$ vs. 3 
Table 2 - Systolic blood pressure, diastolic blood pressure (mean $\pm \mathrm{SD}, \mathrm{mm} \mathrm{Hg}$ ) and hypertension prevalence in employees of a university general hospital according to variables related to job positions.

\begin{tabular}{|c|c|c|c|c|}
\hline Variable & Number $(\%)$ & $\begin{array}{l}\text { Systolic blood } \\
\text { pressure }\end{array}$ & $\begin{array}{l}\text { Diastolic blood } \\
\text { pressure }\end{array}$ & $\begin{array}{c}\text { Hypertension } \\
\text { prevalence }(\%)^{*}\end{array}$ \\
\hline \multicolumn{5}{|l|}{ Job * } \\
\hline 1. Physician & $88(11)$ & $116 \pm 11$ & $78 \pm 10$ & 17 \\
\hline 2. Registered Nurse & $43(5)$ & $116 \pm 15$ & $77 \pm 10$ & 26 \\
\hline 3. Auxiliary nurse & $188(23)$ & $117 \pm 15$ & $77 \pm 13$ & 18 \\
\hline 4. Nurse aid & $44(5)$ & $121 \pm 17$ & $79 \pm 11$ & 39 \\
\hline 5. Nurse Technician & $4(<1)$ & $132 \pm 20$ & $86 \pm 7$ & 50 \\
\hline Nursing Total & $279(34)$ & $117 \pm 16$ & $77 \pm 12$ & 23 \\
\hline 6. Administrative and Management & $84(10)$ & $123 \pm 21$ & $81 \pm 13$ & 33 \\
\hline 7. Skilled performance & $62(8)$ & $112 \pm 13^{\sigma}$ & $76 \pm 8$ & 11 \\
\hline 8. Semi-skilled performance & $183(23)$ & $123 \pm 17^{\alpha \gamma \theta}$ & $80 \pm 12$ & 31 \\
\hline 9. Non-skilled performance & $30(4)$ & $134 \pm 25^{\alpha \beta \gamma \theta}$ & $88 \pm 18^{\alpha \beta \gamma \delta \theta \varepsilon}$ & 47 \\
\hline 10. Non-operational tasks & $75(9)$ & $120 \pm 18^{\phi}$ & $79 \pm 12^{\mathrm{f}}$ & 28 \\
\hline 11. Services & $8(<1)$ & $117 \pm 7$ & $75 \pm 6$ & 12 \\
\hline "Others" total & $442(55)$ & $121 \pm 18 \dagger$ & $80 \pm 12 \ddagger$ & $29 \dagger$ \\
\hline \multicolumn{5}{|l|}{ Work Unit * } \\
\hline 1. Central Institute & $333(41)$ & $118 \pm 16$ & $78 \pm 12$ & 26 \\
\hline 2. Ambulatory Building & $47(6)$ & $113 \pm 11$ & $74 \pm 9$ & 13 \\
\hline 3. Heart Institute & $113(14)$ & $118 \pm 15$ & $79 \pm 10$ & 23 \\
\hline 4. Children's Institute & $80(10)$ & $119 \pm 17$ & $79 \pm 11$ & 26 \\
\hline 5. Institute of Orthopedics & $66(8)$ & $119 \pm 17$ & $78 \pm 12$ & 18 \\
\hline 6. Institute of Psychiatry & $35(4)$ & $123 \pm 17$ & $82 \pm 14$ & 23 \\
\hline 7. Institute of Radiology & $20(2)$ & $124 \pm 19$ & $80 \pm 14$ & 40 \\
\hline 8. $\mathrm{MIL}_{* *}$ & $15(2)$ & $123 \pm 19$ & $82 \pm 16$ & 27 \\
\hline 9. Rearguard Hospital & 29(4) & $119 \pm 16$ & $78 \pm 11$ & 21 \\
\hline 10. Administration Building & $71(9)$ & $129 \pm 22^{\alpha \beta \gamma \delta \varphi}$ & $83 \pm 14^{\beta}$ & 42 \\
\hline \multicolumn{5}{|l|}{ Years of work* } \\
\hline 1. $<1$ & $33(4)$ & $111 \pm 7$ & $72 \pm 10$ & 0 \\
\hline 2. $1-5$ & $168(21)$ & $115 \pm 15$ & $75 \pm 11$ & 14 \\
\hline 3. $5-10$ & $138(17)$ & $118 \pm 16$ & $79 \pm 12^{\alpha}$ & 21 \\
\hline 4. $10-20$ & $310(38)$ & $120 \pm 17^{\alpha \beta}$ & $79 \pm 12^{\alpha \beta}$ & 28 \\
\hline 5. $20-30$ & $133(16)$ & $127 \pm 18^{\alpha \beta \gamma \delta}$ & $83 \pm 12^{\alpha \beta \gamma \delta}$ & 41 \\
\hline 6. $>30$ & $28(3)$ & $129 \pm 25^{\alpha \beta \gamma}$ & $80 \pm 12$ & 43 \\
\hline \multicolumn{5}{|l|}{ Work shift } \\
\hline 1. Daytime & $671(84)$ & $120 \pm 17$ & $79 \pm 12$ & 26 \\
\hline 2. Nighttime & $56(7)$ & $121 \pm 17$ & $80 \pm 14$ & 25 \\
\hline 3. $12 / 36 \mathrm{~h}$ & $76(9)$ & $121 \pm 19$ & $80 \pm 15$ & 26 \\
\hline
\end{tabular}

$* P<.05$ regarding job, work unit, and years of work; **MIL = Medical Investigation Laboratories; $\alpha: P<.05$ vs $1 ; \beta: P<.05$ vs $2 ; \gamma: P<.05$ vs 3; $\delta: P<.05$ vs 4; $\varphi$ : $P<.05$ vs 5; : $P<.05$ vs 6; $\theta: P<.05$ vs 7 ; $\varepsilon: P<.05$ vs 8 ; f: $P<.05$ vs 9 ; $\dagger P<.05$ vs members of the nursing staff and physicians; $\$ P<.05$ vs nursing staff

Table 3 - Systolic blood pressure, diastolic blood pressure (mean $\pm \mathrm{SD}, \mathrm{mm} \mathrm{Hg}$ ) and hypertension prevalence in employees of a university general hospital according to body mass index.

\begin{tabular}{|c|c|c|c|c|}
\hline Body Mass Index* & Number (\%) & $\begin{array}{l}\text { Systolic blood } \\
\text { pressure }\end{array}$ & $\begin{array}{l}\text { Diastolic blood } \\
\text { pressure }\end{array}$ & $\begin{array}{c}\text { Hypertension } \\
\text { prevalence }(\%)^{*}\end{array}$ \\
\hline 1. Low body weight $(<18.5)$ & $14(2)$ & $110 \pm 8$ & $72 \pm 10$ & 0 \\
\hline 2. Normal (between 18.5 and 24.9) & $390(49)$ & $117 \pm 16$ & $77 \pm 11$ & 15 \\
\hline 3. Overweight (between 25.0 and 29.9) & 291(36) & $122 \pm 17^{\beta}$ & $81 \pm 11^{\beta}$ & 33 \\
\hline 4. Obesity I (between 30.0 and 34.9) & $81(10)$ & $122 \pm 19$ & $81 \pm 13^{\beta}$ & 38 \\
\hline 5. Obesity II (between 35.0 and 39.9) & $17(2)$ & $131 \pm 18^{\alpha \beta}$ & $88 \pm 18^{\alpha \beta}$ & 65 \\
\hline 6. Obesity III (>40) & $6(1)$ & $134 \pm 22^{\alpha}$ & $95 \pm 16^{\alpha \beta \gamma \delta}$ & 100 \\
\hline
\end{tabular}

* $P<.05 ; \alpha: P<.05$ vs $1 ; \beta: P<.05$ vs $2 ; \gamma: P<.05$ vs $3 ; \delta: P<.05$ vs 4

"high blood pressure disease."

Hypertension prevalence in terms of job positions, ie, physicians, nursing staff, and others, was $17 \%, 23 \%$, and $29 \%$, respectively $(P<.05)$ in the employees studied; it was $8 \%, 23 \%$, and $23 \%(P>.05)$ in women and 24\%, $21 \%$, and $38 \%(P<.05)$ in men.

The univariate analysis showed that hypertension was significantly associated $(P<.05)$ with the male gender, older age, non-white skin color, low educa- tional level, family income lower than US\$400.00, and obesity. Considering the aspects related to job position, hypertension was observed more often $(P$ $<.05)$ in occupations classified as "others" (jobs related to administration and 
management), in the Institute of Radiology and the Administration Building; and in employees with longer years of work. There was no difference regarding work shifts (Tables 1 and 2).

The univariate analysis (Table 4) showed a significant odds ratio for the male gender, age $\geq 50$ years, work unit in the Institute of Radiology and the Administration Building, education level $\leq$ elementary school, length of work $\geq 10$ years, and BMI $\geq 30 \mathrm{~kg} / \mathrm{m}^{2}$.

The multivariate logistic regression model (Table 5) revealed, with a sensitivity of $71.6 \%$ and specificity of $70.1 \%$ with the probability of 0.26 , that of all variables submitted to the analysis gender, age, skin color, education, family income, job position, work unit, work shift, length of work, and body mass index only the variables gender, age, skin color, family income, and body mass index had a statistically significant association with hypertension. Therefore, in terms of age, the risk of developing hypertension increases $7.9 \%$ for each additional year of life. Concerning body mass index, the risk of having hypertension was $17.3 \%$ higher for each additional unit in BMI $\left(1 \mathrm{~kg} / \mathrm{m}^{2}\right)$. Regarding gender, men were $49 \%$ more likely to have hypertension than women. Analyzing the skin color, nonwhite individuals were $54.7 \%$ more likely to have hypertension than the white individuals. Finally, regarding family income, the employees whose family income was lower than US\$400.00 were $65.5 \%$ more likely to have hypertension. The estimated prob- abilities of hypertension according to the criterion adopted, at levels either reported before or at the moment of the measurement, according to gender, age, skin color (white or not white), family income (higher or lower than US\$400.00), and BMI, are presented graphically in Figure 1. Thus, for example, according to the data showed in the upper left panel in Figure 1, a white female employee, at the age of 40 , with a family income higher than US\$400.00 and a BMI of 35, has a 40\% chance to have hypertension according to the criteria applied in this study. On the other hand, according to the data shown in the lower right panel in Figure 1, a non-white female employee at the age of 40, having a family income lower than US\$400.00 and the same BMI of 35 , is $65 \%$ more likely to present hypertension.

\section{DISCUSSION}

The main finding of this study is that the prevalence of hypertension in

Table 4 - Results of the univariate analysis (odds ratio) in employees of a university general hospital.

\begin{tabular}{|c|c|c|c|}
\hline \multirow{2}{*}{$\frac{\text { Variable }}{\text { Gender }}$} & \multirow[t]{2}{*}{ Odds ratio } & \multicolumn{2}{|c|}{ Confidence Interval (95\%) } \\
\hline & & & \\
\hline Female & - & - & - \\
\hline Male & 1.56 & 1.07 & 2.26 \\
\hline \multicolumn{4}{|l|}{ Age } \\
\hline$>50$ years & - & - & - \\
\hline$\geq 50$ years & 3.29 & 2.19 & 4.97 \\
\hline \multicolumn{4}{|l|}{ Skin color } \\
\hline White & - & - & - \\
\hline Non-white & 1.37 & 0.96 & 1.96 \\
\hline \multicolumn{4}{|l|}{ Education } \\
\hline$>$ Elementary & - & - & - \\
\hline$\leq$ Elementary & 1.93 & 1.29 & 2.88 \\
\hline \multicolumn{4}{|l|}{ Family Income } \\
\hline$\geq \mathrm{US} \$ 400.00$ & - & - & - \\
\hline$<$ US\$400.00 & 1.37 & 0.89 & 2.10 \\
\hline \multicolumn{4}{|l|}{ Job } \\
\hline Physician & - & - & - \\
\hline Nursing staff & 1.34 & 0.67 & 2.69 \\
\hline "Others" & 1.32 & 0.69 & 2.56 \\
\hline \multicolumn{4}{|l|}{ Work Unit } \\
\hline Other Units & - & - & - \\
\hline $\begin{array}{l}\text { Institute of Radiology and } \\
\text { Administration Building }\end{array}$ & 1.79 & 1.07 & 2.99 \\
\hline \multicolumn{4}{|l|}{ Years of work } \\
\hline$<10$ years & - & - & - \\
\hline$\geq 10$ years & 2.54 & 1.71 & 3.78 \\
\hline \multicolumn{4}{|l|}{ Body Mass Index } \\
\hline$<30 \mathrm{~kg} / \mathrm{m}^{2}$ & - & - & - \\
\hline$\geq 30 \mathrm{~kg} / \mathrm{m}^{2}$ & 2.83 & 1.80 & 4.44 \\
\hline
\end{tabular}

Table 5 - Results of the multivariate logistical regression model for hypertension in employees of a university general hospital.

\begin{tabular}{|c|c|c|c|c|c|}
\hline Variable & Estimated Parameter & Standard Error & Odds ratio & \multicolumn{2}{|c|}{ Confidence Interval (95\%) } \\
\hline Interceptor & -8.9691 & 0.7653 & & & \\
\hline Age (years) & 0.0765 & 0.0099 & 1.0790 & 1.0590 & 1.1000 \\
\hline Body mass index $\left(\mathrm{kg} / \mathrm{m}^{2}\right)$ & 0.1594 & 0.0216 & 1.1730 & 1.1240 & 1.2240 \\
\hline Gender & 0.3994 & 0.1896 & 1.4910 & 1.0280 & 2.1620 \\
\hline Skin color & 0.4362 & 0.1889 & 1.5470 & 1.0680 & 2.2400 \\
\hline Family Income & 0.5038 & 0.2168 & 1.6550 & 1.0820 & 2.5310 \\
\hline
\end{tabular}

$\mathrm{N}=794$; Probability $=.26$; Sensitivity $=70.3 \%$; Specificity $=70.6 \%$ 
a population of employees who work in the health care area (26\%) is higher than that observed in the general population $(22 \%)$ of the city of São Paulo. ${ }^{6}$ However, this percentage is lower than the prevalence observed in the general population in the town of Cotia (metropolitan area of São Paulo) with $48 \%$ in men and $41 \%$ in women, or in cities of the State of São Paulo such as Araraquara (28\%), Catanduva (31\%), and Piracicaba (33\%). ${ }^{4,2,7}$

On the other hand, considering that the studied population was hospital employees, the prevalence obtained is much higher than that observed in a previous study carried out in the population of hospital employees $(8 \%)^{15}$. However, since that study was conducted in a military hospital, its population might have presented different characteristics from those observed in the population analyzed in the present study, leading to such a difference in the prevalence.

Concerning the demographic data-gender, age, skin color, education, and family income-the prevalence followed the characteristics that were already known for hypertension: it is higher in men, in older age groups, among non-white individuals, and in those who have a low level of education and low family income.

The employee's job position influenced the blood pressure level and hypertension prevalence in that the employees whose job positions fell in the "others" category presented both higher blood pressure levels and also higher hypertension prevalence than physicians and members of the nursing staff. Moreover, they presented low educational level, low family income, and high body mass index, confirming studies ${ }^{17-19}$ that report that hypertension prevalence is higher among employees with low-skilled jobs, with lower social economical status and unhealthy lifestyles that predispose them to obesity. Regarding the work units, there was a higher percentage of hypertensive individuals at the Institute of Radiology and at the Administration Building. This finding may be due to the fact that most employees there fell on "others" job category. Excessive psychological demand at work, excessive work, and a short time to perform it, coupled with many demands added to the little control and decision-making at work are stressful stimuli that increase the risk of hypertension up to $80 \%$ and can be taken into account in the analysis of the differences observed..$^{20}$

Although important differences in prevalence were found according to job positions, the strong influence of vari-
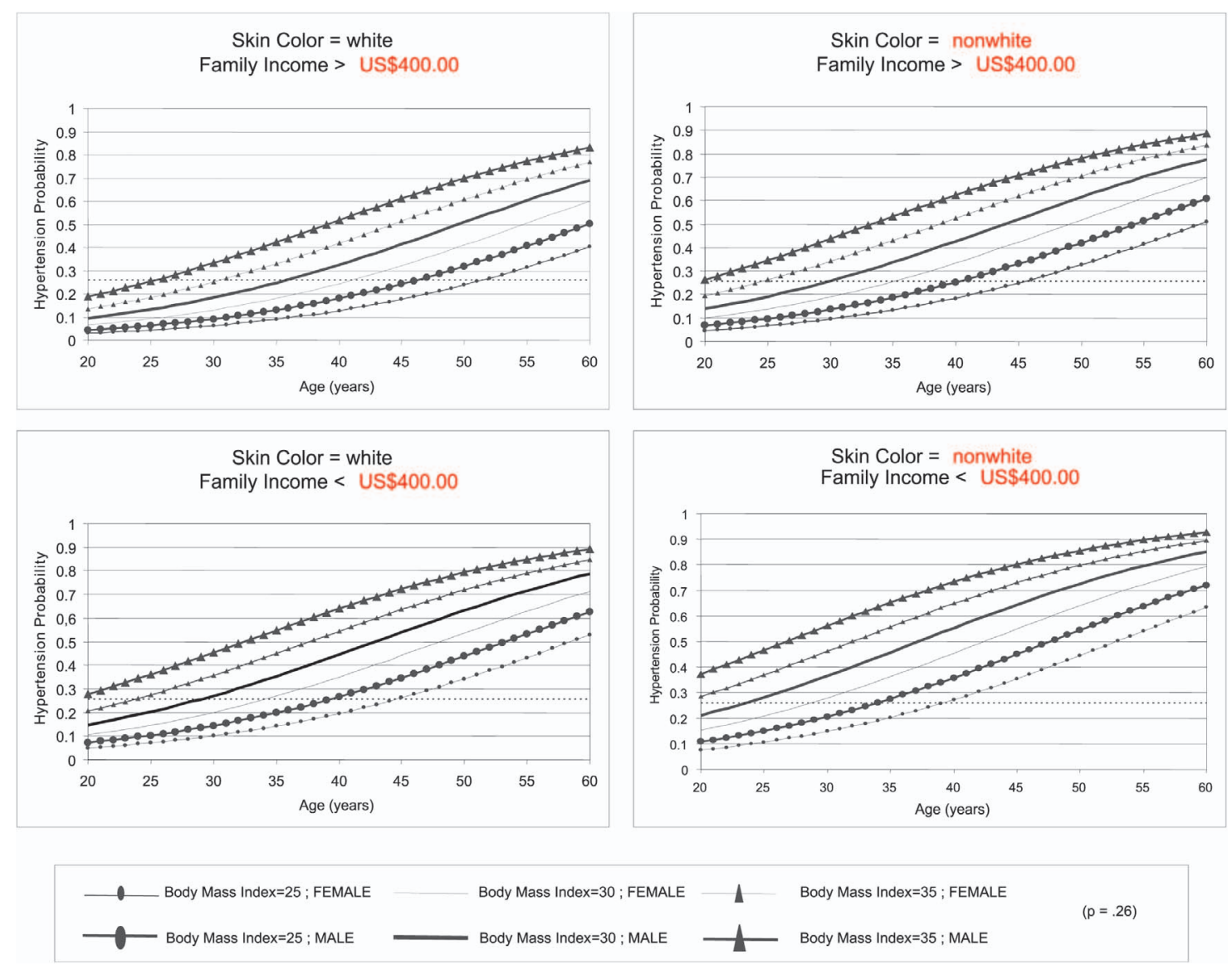

Figure 1 - Probability of being hypertensive according to gender, age, skin color (white or nonwhite), body mass index and family income (more or less than US\$400.00) based on the logistic regression model in employees of a University General Hospital. 
ables such as gender, age, skin color, family income, and body mass index was confirmed once more by means of multivariate analysis. Job positions were not included in the logistic regression model because the other variables had stronger influences on the probability of developing hypertension. The large probability differences found with regard to job position were probably due to the fact that the job position is strongly related to education, family income, and skin color.

Findings of higher prevalences of hypertension in men and the increase of blood pressure with age were reconfirmed. Concerning skin color and family income, the results of the present study confirmed the strong association of blood pressure increase with non-white skin color and low family income. It is important to highlight that this fact should be analyzed inside the social economical context since non-white people as well as their descendants often have lower social economical levels and consequently lower educational level and family income. Education, even if not the final multivariate analysis model, should be taken into account due to the association between higher blood pressure and lower educational level. Explanations for the association between social economical status and blood pressure can be related to 3 special factors: access to health services, including diagnosis and blood pressure control treatment; establishment of blood pressure determinants such as obesity, alcohol, and physical activity; and psy- chosocial factors.

Regarding the body mass index, the already established association between body weight increase and hypertension was also observed, considering that $33 \%$ of the employees who were overweight and $46 \%$ of those who were obese were hypertensive individuals. It is important to point out that almost half of the employees had a BMI that was above normal, probably caused by unhealthy lifestyles. Several studies have reported that hypertension risk increases progressively with elevated BMI rates. In a representative sample from Porto Alegre, Brazil, it was observed that obesity analyzed by BMI was associated with hypertension prevalence in both genders. ${ }^{21}$

Thus, this study highlighted the strong influence of demographic and social economical factors on blood pressure increase, revealing the importance of hypertension among employees of the Brazilian health care area and reinforcing the need for hypertension prevention and control. Since it is a distinct population that is involved with a hospital environment and, consequently, can have access to information, prevention methods, early disease diagnosis and treatment, a lower hypertension prevalence was expected to be found. However, the results show the need for special programs at the workplace for higher-risk groups, such as those whose job fell in the "others" category, as well as males, the elderly, non-white, those whose family income and educational levels are low, and those who are obese. These special programs should focus on facilitating the adoption of healthy lifestyles and measures to prevent high blood pressure, favoring early diagnosis of the disease and hypertension control.

This study was possibly limited by a couple of factors. First, blood pressure was analyzed only once. Therefore, hypertension prevalence based on the criterion of blood pressure increase at the moment of the measurement may be overestimated. However, most of the studies of this nature do not take blood pressure measurements on numerous occasions. A second limitation was that the reported awareness of having hypertension was included in the calculation of hypertension prevalence. Although patient-reported diagnoses could be mistaken, a study carried out in employees at Rio de Janeiro State University showed good reproducibility of reported diagnosis history and hypertension treatment. ${ }^{22}$

\section{ACKNOWLEDGEMENTS}

We are grateful for the invaluable cooperation of Dr. Anacleto Valtorta, Technical Director of the Health Service; Mr. Jorge Luiz Torrezan, Technical Assistant of the Human Resources Department and Nurse Josiane Lima, of the Hypertension Laboratory; Dr. Olavo Mion and Dr. Renata C. Di Francesco, of the Otorhinolaryngology Service; Ms. Tatiana Sales and Ms. Maria Elisa Emiliano; Ms. Júlia Fukushima, statistician and all the employees who agreed to participate in the study.

\section{RESUMO}

MION D e col. Hipertensão arterial em funcionários de um Hospital Universitário. Rev. Hosp. Clín. Fac. Med. S. Paulo 59(6):329-336, 2004.

OBJETIVO: Conhecer a preva- lência de hipertensão arterial em funcionários de um complexo hospitalar e relacionar com variáveis sócio demográficas.

MÉTODOS: Foi medida a pressão arterial com aparelho de coluna de mer- cúrio e manguito adequado à circunferência do braço, o peso e a altura em amostra de 864 dos 9.905 funcionários do Hospital Universitário estratificada de acordo com sexo, idade e ocupação.

RESULTADOS: A prevalência de 
hipertensão foi de $26 \%$ (hipertensão referida $=62 \%$ ou pressão sistólica $\geq 140$ e/ou $\geq 90 \mathrm{~mm} \mathrm{Hg}$ no momento da medida $=38 \%)$. Dos que referiram $51 \%$ estavam hipertensos no momento da medida. A prevalência foi 17, 23 e $29 \%$ ( $p<0,05)$ nos médicos, enfermagem e "outros". Análise univariada mostrou "odds ratio" significante para o sexo masculino, idade $\geq 50$ anos, unidade de trabalho para o Instituto de Radiologia e Prédio da Administração, escolaridade $\leq$ primeiro grau, tempo de trabalho $\geq 10$ anos e índice de massa corporal (IMC) maior ou igual a 30 $\mathrm{kg} / \mathrm{m}^{2}$. O modelo de regressão logística com procedimento "stepwise" mostrou associação estatisticamente significante com hipertensão arterial para as variáveis: sexo, idade, cor da pele, renda familiar e IMC.

CONCLUSÃO: A prevalência de hipertensão foi alta em funcionários do Complexo Hospital das Clínicas, principalmente nos de ocupação diferente de médico e enfermagem. Os grupos de maior risco (homens, cor preta, baixa renda familiar, obesos) precisam ser orientados quanto a prevenção e diagnóstico precoce da doença através de programas especiais.

UNITERMOS: Hipertensão arterial. Medida da pressão arterial. Funcionários. Hospital.

\section{REFERENCES}

1. Lessa I. Epidemiologia da hipertensão arterial. In: LESSA I. O adulto brasileiro e as doenças da modernidade: Epidemiologia das doenças crônicas não transmissíveis. $1^{0}$ ed. São Paulo e Rio de Janeiro, SP e RJ, Hucitec/Abrasco, 1998. p. 77-96.

2. Freitas OC, Resende de Carvalho F, Marques Neves J, Veludo PK, Silva Parreira R, Marafiotti Goncalves R, et al. Prevalence of hypertension in the urban population of Catanduva, in the State of Sao Paulo, Brazil. Arq Bras Cardiol 2001;77(1):9-21.

3. Fuchs FD, Moreira LB, Moraes RS, et al. Prevalência de hipertensão arterial sistêmica e fatores associados na região urbana de Porto Alegre: estudo de base populacional. Arq Bras Cardiol $1995 ; 63: 473-9$

4. Lolio CA. Prevalência de hipertensão arterial em Araraquara. Arq Bras Cardiol 1990;55(3):167-73.

5. Martins IS, Marucci MF, Velasquez-Melendez G, et al. Doenças cardiovasculares ateroscleróticas, dislipidemias, hipertensão, obesidade e diabetes melito em população da área metropolitana da região Sudeste do Brasil. III - Hipertensão. Rev Saúde Pública 1997;31(5):466-71.

6. Rego RA, Berardo FA, Rodrigues SS. et al. Risk factors for chronic non-communicable diseases: a domiciliary survey in the municipality of Sao Paulo, SP (Brazil). Methodology and preliminary results. Rev Saúde Pública 1990;24(4):277-85.

7. Ayres JE. Prevalence of hypertension in the city of Piracicaba. Arq Bras Cardiol 1991;57:33-6.

8. Ribeiro MD, Ribeiro AB, Stabile NC et al. Prevalência de hipertensão arterial na força de trabalho da grande São Paulo: influência da idade, sexo e grupo étnico. Rev Ass Med 1982; 28:209-11.

9. Melhado JC, Mosa AAP, Dine JM. Avaliação de níveis de pressão arterial em operários da construção civil. Revista Brasileira de Saúde Ocupacional 1984;45(12):68-73.

10. Chor D. Hipertensão arterial entre funcionários de banco estatal no Rio de Janeiro. Hábitos de vida e tratamento. Arq Bras Cardiol 1998;71(5):653-60.

11. Nogueira AR, Alves PM, Miranda RF et al. Colesterol e outros fatores de risco cardiovascular nos servidores da UFRJ. Prevalência e influência de variáveis sociais. Arq Bras Cardiol $1990 \cdot 55 \cdot 227-32$.
12. Cordeiro R, Lima FE, Almeida IM. Pressão arterial em trabalhadores de cortume. Rev Saúde Pública 1998;32:46776

13. Aquino EMLL, Magalhães LBNC, Araújo MJ, et al. Hipertensão arterial em trabalhadoras de enfermagem-padrão de ocorrência, diagnóstico e tratamento. Arq Bras Cardiol 2001; 76:197-202

14. Dioguardi GS, Pimenta J, Knoplic J, et al. Fatores de risco para doenças cardiovasculares em médicos. Dados preliminares do projeto VIDAM da Associação Paulista de Medicina. Arq Bras Cardiol 1994;62:383-8.

15. Facci Jr C, Carvalho JJM, Facci A, et al. Prevalência de hipertensão arterial nos funcionários de um hospital geral. Arq Bras Cardiol 1986;46:195-8

16. IV Diretrizes Brasileiras de Hipertensão Arterial. Hipertensão 2002;5(4):126-63.

17. Helmert U, Mielck A, Classen E. Social inequities in cardiovascular disease risk factors in East and West Germany. Soc Sci Med 1992;35:1283-92.

18. Singh RB, Sharma JP, Rastogi V, Niaz MA, Singh NK. Prevalence and determinants of hypertension in the Indian social class and heart survey. J Hum Hypertens 1997;11(1):51-6.

19. Bone LR, Hill MN, Stallings R, Gelber AC, Barker A, Baylor I, et al. Community health survey in an urban African-American neighborhood: distribution and correlates of elevated blood pressure. Ethn Dis 2000;10(1):87-95

20. Schnall PL, Schwartz JE, Landsbergis PA, Warren K, Pickering TG. Relation between job strain, alcohol, and ambulatory blood pressure. Hypertension 1992;19(5):488-94.

21. Gus M, Moreira LB, Pimentel M et al. The association between different measurements of obesity and the prevalence of hypertension. Arq Bras Cardiol 1998;70(23):111-14.

22. Faerstein E, Chor D, Lopes CS. Confiabilidade da História Referida de Diagnóstico e Tratamento de Hipertensão Arterial Diferenciais Segundo Gênero, Idade e Escolaridade. O Estudo Pró-Saúde. Arq Bras Cardiol 2001;76(4):297-300. 